\title{
Nauru Phosphate History and the Resource Curse Narrative
}

Exploitation du phosphate et "malédiction des ressources naturelles" à Nauru: histoire d'un héritage

\section{Nancy J. Pollock}

\section{(2) OpenEdition}

\section{Journals}

Electronic version

URL: http://journals.openedition.org/jso/7055

DOI: $10.4000 /$ jso. 7055

ISSN: $1760-7256$

\section{Publisher}

Société des océanistes

\section{Printed version}

Date of publication: 15 December 2014

Number of pages: $107-120$

ISBN: 978-2-85430-118-2

ISSN: 0300-953x

\section{Electronic reference}

Nancy J. Pollock, «Nauru Phosphate History and the Resource Curse Narrative », Journal de la Société des Océanistes [Online], 138-139 | 2014, Online since 15 December 2017, connection on 10 December 2020. URL : http://journals.openedition.org/jso/7055 ; DOI : https://doi.org/10.4000/jso.7055

\section{cc) (†)}

Journal de la société des océanistes est mis à disposition selon les termes de la Licence Creative Commons Attribution - Pas d'Utilisation Commerciale - Pas de Modification 4.0 International. 


\title{
Nauru Phosphate History and the Resource Curse Narrative ${ }^{1}$
}

by

\author{
Nancy J. POLLOCK ${ }^{*}$
}

\begin{abstract}
Nauruans' experiences of a resource curse from mining phosphate stands, as a case study of retarded development. Nauru was much adulated in the press in the early $X X^{\text {th }}$ century as an example of a "small island" that became "wealthy" through mining. The high grade phosphate that covered four fifths of the island was considered by outsiders as a very lucrative resource that had to be mined, particularly as fertilizer to enhance the pastures of Australia and New Zealand. The development of Nauru has been misinterpreted by attributions of wealth to Nauruans when most of the profits from mining accrued to the mining agencies. Sales of phosphate yielded far greater development to Australian agriculture than to Nauruan owners of the resource. Meanwhile the small island surface of Nauru underwent gradual destruction of its interior retarding any developments, economic or humanitarian.
\end{abstract}

KeYwords: Nauru, phosphate mining, resource curse, retarded development, case study

Nauru phosphate mining is a prime example of "the natural resource curse» thesis (Auty, 1993) as applied to a small island state in the Pacific. Mining did not enhance economic development for Nauruans but rather retarded Nauruan development processes, betraying trusts and

\section{RÉSUMÉ}

L'expérience nauruane des ressources maudites découlant de l'exploitation du phosphate constitue un cas emblématique de prévention du développement. Nauru a été acclamé dans la presse du début du XX siècle comme un exemple de "petites îles" devenue "riches" grâce à l'exploitation minière. Le minerai à haute teneur en phosphate qui couvrait les quatre cinquièmes de lîle était considéré dans le reste du monde comme une ressource lucrative à extraire, en particulier pour fertiliser les prairies australiennes et néozélandaises. Le développement de Nauru a mal été interprété, sur la base des richesses distribuées aux habitants, alors que l'essentiel des profits miniers revenait en réalité aux opérateurs miniers. Le commerce du phosphate a rapporté beaucoup plus à l'agriculture australienne qu'aux propriétaires nauruans de la ressource en question. Et cet enrichissement très relatif a eu pour conséquence la destruction progressive de la surface de la petite île de Nauru, empêchant tout développement, quil soit économique ou humain.

Mots-clés : Nauru, exploitation du phosphate, malédiction des ressources, frein au développement, étude de cas

creating reliance on outside agencies, so necessary for a small population on a single island in midPacific. Mining has had a long term impact on Nauruans and their island (Pollock, 2014). This paper illustrates what Rosser (2006) terms the consensus of how "political and social variables

1. I am grateful to the Nauru Government and AusAid for support for participation in the Commission of Enquiry into Worked Out Mines on Nauru, 1986-88. I am also grateful to Professor Harry Maude for sharing his early notes on Nauru.

* Department of Anthropology and Development Studies, Victoria University, Wellington, New Zealand, nancy_pollock@paradise.net.nz 
mediate the relationship between natural resource wealth and development outcomes» in one small Pacific Island nation. The so-called wealth that has drawn much media attention has disrupted political relationships within and exterior to the island, and led to a loss of wealth, both financial, environmental and social. This society thus exemplifies the label "natural resource curse». Nauruans had to seek compensation from the British Phosphate Commissioners (вРC) for failure to rehabilitate environmental destruction, that led to loss of land as the main food source, and loss of administrative control of their own affairs, i.e. autonomy. They received miniscule benefits from the extraction and sales of «their» phosphate, and violation of international trusts that committed BPC to bringing development to Nauru society (Weeramantry, 1992).

We will consider the Nauruan case of mining as «retarded development» by contrasting capitalist views of economic development, i.e. cash dependency, with humanitarian views of development, i.e. of justice and well-being (Sen, 2001). Whereas minute cash returns to a few Nauruans necessitated purchases of basic foods to replace traditional foods, the additional sums deducted by Australian administrators to be placed in Trust Funds, and environmental degradation left Nauruans struggling to survive on their much reduced island space. Nauruans' humanitarian concerns were compromised by their loss of autonomy in the face of mining priorities. Nauruans' call for rehabilitation of their island and compensation for under payments for their phosphate was heard at the International Court of Justice in the Hague, with former British Phosphate Commissioners charged with remedial payments (see Weeramantry, 1992 for details).

The Commission of Enquiry into Worked Out Mines on Nauru (1986-1988), as a joint project between the Nauruan government and AusAid, sought to establish the background to Nauruans' concerns for remedying the damage to their island inflicted by phosphate mining. The Commission of Enquiry brought in a team of advisers ranging from geo-morphologists to a housing advisor and ecological remedial advisers. My role as social scientist liased with the former President Lagi Harris to ascertain the views of Nauruans about the best steps for their future. We held meetings in the twelve districts, talked with concerned Nauruans, and I visited a Class 6 to discuss and have them illustrate their thoughts on their future. As an anthropologist I was concerned that the team capture Nauruans' views of the best remedies for their island's well-being.
The media has labelled Nauruans variously over time as:

"the wealthiest little island in the Pacific [...], most "obese population" on wHO list of BMIs, and "failed state"."

In this paper we examine how Nauruans have experienced little benefits from "wealth» from phosphate during the $\mathrm{xx}^{\text {th }}$ century, but rather inherited a struggle to seek the lost income, buried in Trusts by the вPC. The small income that each Nauruan land holder received at the time her/his piece of land was mined contributed minimally to that family's welfare. And the Trust Funds have contributed little to Nauruans' future security, as discussed below. The lack of rehabilitation of the devastated four fifths of the interior of the island lingers as a humanitarian (and costly) issue that requires vast capitalist resources to render the whole island habitable again, in order to meet Nauruans' hopes for future generations. Nauruans' trust in outsiders' lack of attention to these concerns has been severely compromised.

When economic development is measured in terms of the growth of "wealth" and how that wealth is managed (e.g. Stiglitz, 2006) the Nauruan example reveals contrasting views of that concept. For Nauruans, wealth has always referred to their island, their land, in its spiritual and material entirety, deep down below any surface elements. That was the basis from which Nauruans instituted their claim for compensation from the British Phosphate Commissioners (Weeramantry, 1992; Pollock, 1986). For the Pacific Phosphate Company at the beginning of the $\mathrm{xx}^{\text {th }}$ century and later the British Phosphate Commissioners, wealth was viewed as returns accumulating to their businesses from phosphate sold at cheap prices to themselves. For one party, Nauruans, their wealth has been destroyed by mining; for the other, Australia and New Zealand, wealth was created. These contrasting views of "wealth" underlie the early misrepresentations of Nauru as a wealthy nation.

By tracing the impact of mining phosphate on a small remote Pacific island, we can clarify how economic development has tended to be slower in resource rich countries than in rich nations (Auty, 1993; Sachs and Warner, 2001; Stiglitz, 2006). Most of the mining examples cited by Sachs and Warner are enclaves within larger economic entities that have been classed as developing nations, such as tin mining in Chile. They are also entities where mining has developed recently, i.e. in the last 50 years. In contrast, Nauruans have experienced the "underdevelopments» resultant from mining throughout the $\mathrm{xx}^{\text {th }}$ century (Pollock, 2014). The «natural 


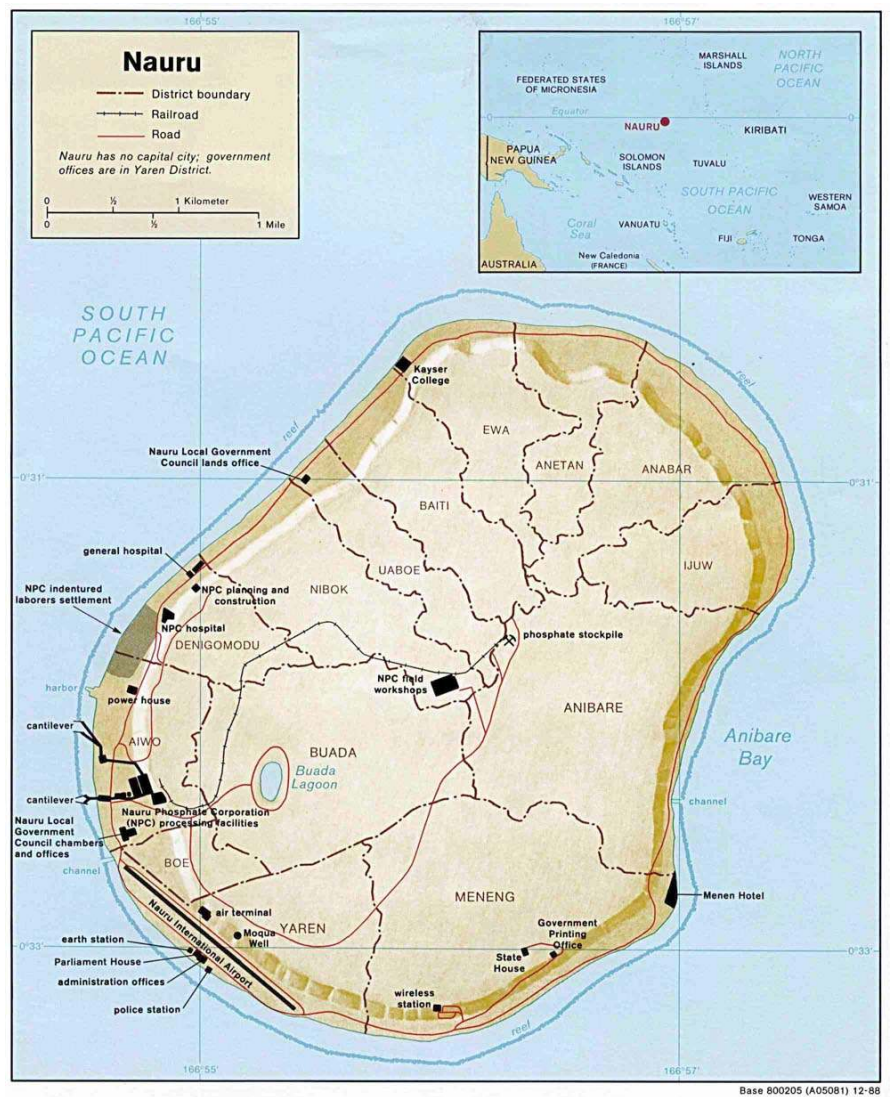

Map 1. - Nauru in the Pacific Ocean

resource curse» has left them with little land to live on, no local resources, limited finances, and a high level of dependency on outside agencies. They must import all necessities, including food and water, using whatever returns their resource has provided throughout the $\mathrm{xx}^{\text {th }}$ century. Today they have become dependent on outside aid to replace their denuded island's wealth.

The Nauru example demonstrates the negative aspects of dependence on cash as an element of capitalism. When returns from the sale of a resource, in this case phosphate, must replace basic subsistence living sources, and when cash returns are miniscule (two pence a ton) to a land holder for a piece of land mined, new problems are presented for everyday living and well-being. In the short term few Nauruans have had cash to meet new demands. In the long term the Trust Funds, derived from money taken from those small sums to be set aside/invested by the Administrators for Nauruans' future needs, have proved to be poorly invested. The gradual destruction of the whole interior of the island has had both short term and long term impacts that Nauruans themselves have had to address. The result, in the $\mathrm{xxI}^{\mathrm{st}}$ century is an island population crowded into a narrow shore-line strip totally dependent on outside sources, including food and water, that must be transported across many thousand miles of the Pacific Ocean.

\section{Socio-Cultural Background to Mining}

When mining began in 1906, the Nauruan population was less than 1,000 people. A civil war in the 1880 s, fuelled by traders, mainly German, selling guns and gin, led to the "Queen" of all Nauruan tribes approaching Germany for assistance to bring peace to what had been labelled by earlier visitors as «pleasant island». As a German colony, tribal organization was reformulated for administrative purposes (see Clark and Firth 1992), but Nauruans continued to maintain their traditional structure of leadership of tribes, districts and family mobility of allegiances. Tribal organization was further reviewed in 1927 when the British Phosphate Commissioners introduced a new Council of Chiefs through which to administer both Nauruan social relationships and mining the land. Nauruans maintained their tribal structure alongside the new imposed political structure. In 1952, Nauruans established a less hierarchical structure for themselves in the form of the Nauru Local Government Council. Importantly, it gave them a separate voice to the United Nations Visiting Missions to whom they expressed their growing list of concerns.

The onset of mining in 1906 drew Nauruans into a transitional status. Their traditional tribal organisation, social hierarchy and supporting customs and practices provided the fundamental basis for their living and wellbeing. Each Nauruan belonged to the tribe of her or his mother. S/he was also born into a twotiered social system, headed by the Temonibe class, with younger kinsmen belonging to the Amengename class. Newcomers comprised the Itsio class who became attached as residents and workers to a particular tribal chief who conferred on them rights to live on and work on a particular land. The Nauruan social system was clearly established; it enabled outsiders such as beachcombers and traders to be given a place in the system, albeit as outsiders (itsio). The Nauruan social system revolved around women as the procreators of new members of each of the twelve tribes, and some were recognised as chiefs. The tribal system has survived the turmoil of the $\mathrm{xx}^{\text {th }}$ century (Pollock, 2014). 
Given the scarcity of basic resources, and their strong attachment to their land, Nauruans had devised a social system that organised the best means of allocating resources among the resident population, including rights to land. Individuals inherited rights to named pieces of land through both their mothers and fathers, but shared those rights with kin. Their class system, as linked to a complex chiefly system that controlled the twelve tribes, and responsibilities to the twelve districts persisted despite the administrators attempts to apply new means of controlling Nauruans, alongside other residents.

Nauruan leadership emerged to express their concerns about injustices. Timothy Detudamo expressed their expectations for a greater share of the phosphate wealth with BPC throughout the 1920a and 1930s, and Hammer de Roburt took up his role after Nauruans returned from exile in 1946. When Nauruans decided in 1952 to update their system, they formed the Nauru Local Government Council that replaced the hierarchy of the class system, with elected representation of the people. That lasted through into the 1990s. Their submissions to the United Nations Visiting Missions built their case for independence; Hammer de Roburt became President intermittently from 1970 onwards until his death. Nauruans continued to manage their affairs according to their own principles, despite attempts to impose alternative controls. Autonomy persists as all important among those principles.

\section{Demographic Imbalance}

Nauruans were concerned that their small numbers, amounting to 1,084 in 1921, contributed to their lack of voice with the Australian administrators. They were vastly outnumbered $(2: 1)$ by the mining contract labour force and mining administrators. Reproduction of their tribal groups has been an ongoing concern for Nauruans. Given the limited resources to feed the population and fears that any one tribe may die out, they had set in place a cultural system of channelling the best food resources to a young woman at menarche (Pollock, 1995, 2012). A young woman's fertility was preciously guarded and socially supported; a fattening process ensured she had the best chance to produce a healthy offspring (Pollock, 1995). Directing scarce resources towards successful reproduction was a major cultural feature, necessary to support the desired increases to the population.

That concern to increase the Nauruan population has been retained throughout the $\mathrm{Xx}^{\text {th }}$ century; very few Nauruans have migrated away from their island. Population growth has continued to be supported, whereas in other parts of the Pacific, plans to restrict population growth have been set in place. At the turn of the XIX $^{\text {th }}$ century Nauruans had established a target of 1,500 both as a necessary feature for retaining autonomy on their island, as well as for gaining recognition by their administrators. Contract labourers brought in in large numbers from 1906 onward placed Nauruans in third place behind the administration and mining managers and an ever-growing labour force. Development was curtailed by their low numbers, as it was dispersed amongst all residents.

That target population goal of 1,500 (Kretzschmar, 1913) was finally reached in 1933 . They had lost men during the civil war of the 1880s, and a flu epidemic in 1905, and the big Pacific wide flu epidemic of 1919 severely set back their population growth. Thus the birth of the $1,500^{\text {th }}$ Nauruan in October 1933 was a major event that is still celebrated annually on the Nauruan calendar today. Nauruan autonomy has been based around rebuilding the numbers of Nauruans and their rights.

\section{Retarded Development}

Views of development as benefits derived from a cash economy that would «trickle down» to the wider populace have been critiqued by those who have witnessed its failures, resulting in widening gaps between poor and rich (e.g. Sachs and Warner, 2001; Stiglitz, 2006). Instead, views of development based on a "bottom up» approach stress the need to broaden the development concept to include humanitarian concerns, such as ready access to basic needs (i.e. assured food supplies), to address health and education facilities, and most importantly recognition of and respect for peoples' rights to autonomy and decision making according to their own values (Sen, 2001). Environments can be assessed from both standpoints; the Nauruan case, successfully heard before the International Court of Justice in The Hague, serves as case law that indicates that an island community's environment was more than just commercial property for others to exploit (Weeramantry, 1992). The hearings pointed out that BPC had failed to advance the development of Nauru society as entrusted to them by the League of Nations Mandate, followed by the United Nations Trusteeship.

\section{Cash Dependency}

The "wealth" that was so frequently attributed to Nauruans during the first half of the $\mathrm{xx}^{\text {th }}$ century in media reports is a myth, built up 
and repeated by those who were more familiar with the increased productivity that phosphate brought to Australian and New Zealand farmers, than with the realities that Nauruans were experiencing from outsiders' mining interests. If Nauruans had been receiving their rightful share of profits from the sale of their phosphate then they might have been wealthy in a capitalist sense, even though they had lost half the usable living space on their island. Dependency has become a high price to pay for their resource curse, especially for a population highly desirous to maintain their autonomy. The rentier economy that overrode Nauruans' rights became their underlying point of contention at the Commission of Enquiry into Worked out mines in 1986 (Weeramantry, 1992).

The British Phosphate Commissioners, when established under the Nauru Island Agreement in 1919, had allotted shares among themselves, so that Australia and the United Kingdom would take $42 \%$ each of the phosphates produced, while New Zealand was allotted $16 \%$. As one uk politician stated:

"We lay down in this Agreement the best phosphates in the world are to be held for the exclusive use of the three nations and in any case are to be sold to them at cost.» (cited in Weeramantry, 1992: 62-3)

No mention was made of any payments to Nauruans - those were for each Australian Administrator to determine later in consultation with Canberra (for terms of the Nauru Island Agreement 1919, see Weeramantry, 1992, Appendix I: 376-378).

This new management of mining replaced the structure initially set in place under German administration and the Pacific Phosphate Company when mining first began in 1906. After World War I when German possessions were redistributed under the League of Nations Mandate, responsibility for Nauru was assigned to the UK, at Australia's particular behest. The status of the mining operation was not specified as a separate entity from development of Nauruan affairs. But the Mandate specified under its provisions that the British Empire, through the Commissioners «as managers of a business concern» was responsible for ensuring:

«not only the present welfare of the natives, but also in conformity with the recommendations of the Covenant, the development of the population of the mandated area.» (cited in Weeramantry 1991, Appendix II: 381)

Similar development obligations were set in place when Nauru became a United Nations Trust Territory after World War II. Nauruans drew attention of successive un Visiting Missions to BPC failures to observe those obligations.

Nauruans lost use of their lands in return for a very small share of those returns. When mining began on plots of land in the south east corner of Top Side two or three land holders received a few pfennigs per ton initially, then two pence per ton of phosphate extracted from her/his land after 1922 when the British Phosphate Commissioners established control of the island and all its resources.

In contrast at that time the вр Commissioners were selling that phosphate to Australia and New Zealand at Australian 4 pounds 52 pence per ton - many hundred per cent profit. And those were mates' rates! - i.e. below open market rates. As Weeramantry has demonstrated (figure 2.1):

«it is important to note that not only was the Nauruan landowner receiving so minute a fraction of the value of the phosphate taken from his land, he was also left with the added burden of the devastation of his land which had been enjoyed by his people from time immemorial.» (Weeramantry, 1992: 23)

In the 1890s, before phosphate was discovered, German surveyors had mapped the land holdings of Nauruans to provide a record of both landholders and the boundaries of their pieces of land. The Pacific Phosphate Company, and subsequently the British Phosphate Commissioners, used that survey record as the basis by which mining was moved from land holding to adjacent land as the template for all successive mining. The mining company recorded the amount of phosphate extracted in a large folio. Against each numbered and named piece of land the tonnage of phosphate, and the amount paid was recorded. The two or three Nauruans who were acknowledged as land owners were paid their 50 pfennig a ton initially, later a half penny per ton rising to two pence per ton in 1922, together with small sums paid to the owners of any coconut trees and pandanus trees on that land that were destroyed by mining. That record, kept in a folio volume in the Lands office on Nauru, was computerized in Melbourne in the 1990s (author's fieldnotes). It provides a clear record of the very small sums that each landholder received at the time when lands were first mined.

Land holders had to replace their pandanus and coconut tree food sources with rice and cans purchased from the mining company store, a further example of BPC's total control of life on Nauru. Each of two or three land holders of each mined plot might be awarded a total of six or ten (British) pounds per ton of phosphate extracted; that money was a once-only income return from that land - nothing more would eventuate after it was mined out. Those small sums of cash paid to 
Nauruans had to be used to buy foods to replace the pandanus and coconuts that the land holder's household had formerly relied on, together with whatever fish they caught as a supplement, as well as for all other means of supporting themselves, such as housing. Furthermore they were culturally bound to share such "luxuries» with kin. Rice and tinned meat were purchased from the "Company (i.e. BPC)» store at inflated prices. When Timothy Detudamo, a Nauruan leader, set up an alternative Cooperative store in the 1920s for Nauruans, he was thrown in gaol.

Their holdings were reduced to a sea of calcite pinnacles. Phosphate «dirt» was dug out (by Chinese contract labourers) from between the hard calcite pinnacles to be processed into superphosphate before being shipped and sold off shore to Australian and New Zealand farmers. The high grade fertilizer rapidly increased the productivity of their pastures. It was sold to them at below market rates.

When the question of whether Nauruans had been adequately compensated for loss of their land was raised in 1957 and 1960 at meetings with the United Nations Trusteeship Council, the BPC representative claimed that:

«there was no world price for phosphate»

and details of the commercial enterprise were confidential [to BPC] and:

«bore no relation to a Trust Territory.» (cited in Weeramantry, 1992: 138)

This argument was used in justification for BPC's failure to provide the Trusteeship Council with full information on their financial operations in regard to Nauru. But Trusteeship Council members continued to press for Nauru's accounts, as Nauruans believed that:

«the Commissioners were making profits at the expense of the Nauruans.» (Weeramantry, 1992: 138)

Nauruans' concerns were at last beginning to reach those considering their rights, rather than just economic returns.

Nauruans were taking note of the discrepancies in cash value, and kept a steady pressure on the Australian administrators for BPC from 1921 onwards to increase returns to land holders. But they were stymied by their small numbers and lack of «voice». Sums were increased gradually from two pence to four pence in 1927 and stayed at that rate until 1939, (but one penny per ton was deducted to be placed in a Royalty Trust Fund, as discussed below). After the mine restarted in 1948 following the devastation of World War II, Nauruan land holders received six pence per ton of phosphate from their land, rising to three shillings and six pence just before Nauruans declared independence in 1968 (Viviani, 1970: 189). By that time two thirds of all the land holdings on Top Side had been mined, and become inaccessible. After independence, Nauruans had to consider whether to continue mining. They decided they needed the income.

Nauruans became consumers with no other choices. They had to buy the new goods including cloth as missionaries and other outsiders expected them to replace their ridi made from pandanus leaves by cloth garments. The Company store provided an array of goods such as Nauruans had never seen before. They were praised for «modernising» by buying items as they could afford them. Consumerism was a mark of modernisation.

The sums those first Nauruan land holders received were miniscule and hardly constituted the label «wealth» as was so oft reported. Rather the wealth was accruing to Australian and New Zealand farmers as they harvested crops grown with the new uncontaminated fertilizer.

\section{Trust Funds}

Australian administrators established a Nauru Royalty Trust Fund in 1921 in answer to Nauruans' demands for a greater share of the returns from phosphate sales. Those administrators decided that since Nauruans were unfamiliar with handling money any increases in returns should be placed out of reach of everyday spending in a Trust Fund; one penny per ton of phosphate exported was added to the 2 pence return to an individual shareholder of the named land from which the phosphate had been taken. The proportion of the sums deducted to be paid into a Trust Fund was increased over time, almost equal to the sum paid direct to landholders as discussed above. Two pence in the hand (direct payments) was matched by one or two pence in the Nauru Royalty Trust Fund on behalf of each land holder.

Subsequent Australian administrators increased the number of Trust Funds over the 47 years between 1920 and 1967. The Nauru Royalty Trust Fund, Nauruan Landowners Royalty Trust Fund, the Nauruan Community Long Term Investment Fund, and a Rehabilitation Fund were added over time. Each Fund was invested by the Australian administration to set aside income for use when the phosphate ran out. The sums invested were not apparent to the UN Visiting Missions in the 1950s and 1960s who sought access to the financial records of the BPC. In addition Nauruans were charged a «management fee» of $10 \%$ of costs deducted from their phosphate returns (Viviani, 1970: 160). Administration costs rose from 3,829 
Figure 1. - Phosphate in Nauru (date, picture Nancy Pollock)

Australian pounds in 1922 to 862,136 pounds in 1966 when they comprised 20\% of the value of phosphate exports in 1966 as taken from sales of phosphates (Vivian, 1970). Weeramantry made a key point during the later compensation hearings (in 1988) that:

«The British Phosphate Commissioners [...]

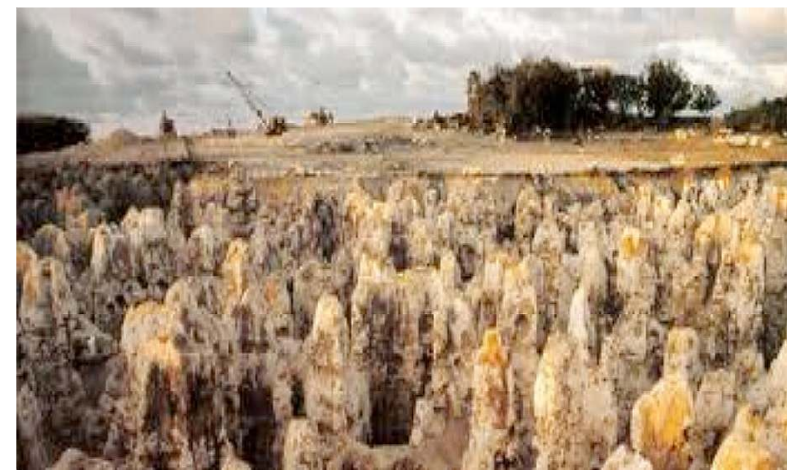
were endeavouring to purchase the phosphates available for the cheapest possible price [...][.] It ensured that the Nauruans would not receive the best possible price for their phosphates.» (Weeramantry, 1992: 104)

Nauruans were thus paying for administration of their island under a League of Nations Class C Mandate out of their phosphate money. The Mandate supposedly protected Nauruan interests, but any development was being paid for out of Nauruans' own small returns.

The various Trust Funds were invested by Australian accountants with little input from Nauruans. Furthermore the financial records of the various funds were so obfuscated that neither the League of Nations nor the United Nations after them was able to ascertain accurately the true position and status of the Nauru accounts. Accounts were secret (Weeramantry, 1992: 105). The Commissioners channelled money into a variety of funds, such as a Capital Assets Replacement Reserve, the Development Reserve and others but the accounts were not revealed to either protective agency nor to Nauruans themselves.

The status of their financial affairs and where money had been invested on their behalf became a major concern for the newly independent Nauru government in 1970. In 1971 they had bought the mining equipment from the Commissioners for $\$ \mathrm{~A} 21$ millions, that they distributed "to countries of their choice» exclusive of Nauru (Weeramantry, 1992: 282). The British Phosphate Commissioners were dissolved in 1987. Their records of 47 years of administering the mine and the island «were not generally available for perusal» to the Nauruan established Commission of Inquiry in the 1980s (Weeramantry, 1992: 69). The new nation was faced with a heavy debt and obscured investments on which hopes were pinned.

In 1970 the new Nauru government inherited a very murky financial picture. They began immediately to try to establish their claims for underpayments from phosphate and betrayal of trust by the British Phosphate Commissioners of their responsibilities to develop Nauruan way of life under the terms of the League of Nations

Mandate and the United Nations Trusteeship. They had to seek advice from outsiders as they had previously been totally excluded from any management roles in the phosphate industry or in administration. Their financial position has posed ongoing major difficulties for Nauruans. They were poorly equipped to uncover such a complex set of books. An irreversible situation continued after independence as the natural resource curse has persisted.

The Trust Funds were supposed to provide money for the support of future generations. Mining advisers to the new Nauru Phosphate Corporation in 1970 suggested that the remaining third of phosphate reserves would last to 1996 at the current rate of mining. The general Nauruan population expected their payouts from their calculated shares of the Royalty Trust Funds, known as Ronron, to be available on that date. Some 6,000 of them had plans in place for spending the money. When a series of governments was unable to provide answers to the people as to how much, and when the payments would commence, Nauruans staged a protest in 1993 at the time the Pacific Islands Forum meeting on Nauru. But the Government has failed to reveal what happened to the funds. In 1997 the United Nations Development Programme revised Nauru's per capita Gross National Product from $\$ \mathrm{~A} 29,110$ million to \$A3,711million (quoted in Quanchi, 2007: 253). Many such figures have been presented depending on how blame is apportioned.

The label «failed state» that has been attached to Nauru and other Pacific Islands (Brown, 2007), has been applied repeatedly by one commentator reffering to Nauruan failures to safeguard their investments for more financial transparency since 1921, and more stridently in the 1950 s, but to no avail. The state of their financial affairs has challenged many outsiders as well as a series of Nauruan governments.

\section{Environmental Degradation}

The costs of mining for Nauruans included environmental destruction of Top-Side, that 
comprises four fifths of the interior of the island. As a raised reef, that interior stood some 200 feet above the coastal strip that marked the shoreline above a narrow encircling reef. The lands holding the "rich source of phosphate» in Australian eyes were degraded piece by piece into a sea of pinnacles which benefits no one, and raises the temperature of the island environment.

Before mining began, the island was noted for its green and pleasant appeal. The trees that covered the island were a point of remark by early visitors, such as Commander Simpson in 1843. They termed Nauru "pleasant island» and a Garden of Eden on account of its lush greenery. (They must have visited after a rainy season, as Nauru is prone to a range of climates varying from heavy downpours to droughts that last two or three years.) But the calcareous base to the island meant that water is always a precious resource. Vegetation that survives these extremes is limited in variety, yet for several hundred years Nauruans had managed their land so as to support a viable population.

After mining, the rich forest was destroyed, leading to ever increasing environmental damage. The interior became a waste-land. Each land holder watched as diggers and machinery carried the dirt, called phosphate, to a processing plant on the coast line, to be transformed into super phosphate, and thence shipped out to waiting vessels that carried the valuable cargo to Australia and New Zealand. Their land was being exported to some distant purchasers, to use as superphosphate to improve their lands, while degrading Nauruan lands.

The process of degradation of Top Side included removal of the two major hillocks that were integral to their heritage. They had had strong spiritual meaning to Nauruans as they were said to represent the landing places of the founding ancestors who arrived from the Gilbert Islands several hundred years earlier to establish a new community (see Pollock, 2014). The early Nauruans had maintained these sites with reverence and awe as part of their heritage and links to the founding ancestors. Bulldozers tore away the soil to stockpile it, regardless of Nauruan protests.

Top-Side had been a tree-covered forest that provided not only useful materials for building, clothing, food and recreation, but the pathways that linked the twelve districts that radiated from a central point on Top Side. It was a central feature of their communication system across the island. But the sea of pinnacles makes such crossings, and other uses, impassable.

The tree cover protected the island from the worst of the heat. Located just fifty miles south of the Equator, the heat takes its toll on both flora and fauna. Trees such as the giant tomano (Calophyllum) had served as the resting place for birds migrating across the Pacific. Noddy terns circled the island, to take up their places in the trees at night. Nauruans captured these as a food source. Giant frigate birds favoured the shore-line as their roosting sites, where they became an important part of Nauruan cultural life; Nauruans regarded them as representing the ancestors, enticing them on shore with offers of fish, and thence to rest, initially in shore line trees. Each tribe maintained frigate bird stands on the shoreline to which the birds learned to return each night. The stands of birds around the island represented the strength of a tribe. As tree cover diminished men built frigate bird stands on the shoreline from scrap wood. The cult of the frigate bird has endured as a key part of Nauruan heritage (Kayser, 1935) despite mining activities. They provide the major icon of Nauruan coat of arms, and on the tails of Nauru's fleet of planes (Pollock, 2009). They represent Nauruans' ties to their island environment.

\section{Humanitarian Concerns}

Nauruans were very aware of their loss of autonomy as BPC took control of their island and began expressing it through pressure on Australian administration officials. That autonomy has been their underlying premise for establishing their rights to claim compensation for underpayments as well as welfare injustices and the right to expect BPC to rehabilitate their island. Financial losses were part of the larger concern for social justice for lost humanitarian rights. Nauruans considered a key factor to be raising their population size - above 1,500 Nauruans - if they were to gain back their rights. Autonomy had been snatched from them, and compensation was necessary. Leadership needed a strong backing. Hence after independence in 1968, Hammer de Roburt and his government began to seek international support for compensation claims and the Rehabilitation exercise.

The distribution of wealth from mining was an economic concern that included many humanitarian concerns. Nauruans brought some 30 years of arguments they had been formulating before the Commission of Enquiry for Rehablitation of Worked out Mines in 1986 (author's fieldnotes). ${ }^{2}$ As Stiglitz has noted for the natural resource curse world-wide:

«the riches that arise from grabbing hold of a nation's natural resources [...] undermines faith in the market economy - when it is suspected that the wealth is acquired "illegitimately" through underhanded deals with current or previous governments. It is not surprising that discontent seethes beneath the surfaces of these countries.» (Stiglitz, 2006: 137) 
In Nauru's case that discontent was expressed by concerted efforts to gain independence in 1968. Subsequently, this led to a Commission of Enquiry for Rehabilitation of Worked out Mines in 1986. The key findings provided the basis for the case brought before the International Court of Justice in The Hague by Professor Weeramantry on Nauru's behalf (see Weeramantry, 1992 for his arguments).

Exclusion from any decision making regarding the direction of «developments», allocation of the profits from mining, compensation for destruction of land, and consideration of Nauruans' rights have been at the forefront of Nauruans' struggles for rectification of the curse of their natural resource. Loss of autonomy has been the major platform for emerging leaders, representing a growing population, and an increasing awareness of the developments denied to them.

\section{Loss of Autonomy}

The Nauru Island Agreement (1919) did not include Nauruans in any of its fifteen articles. Rather it set out the powers of the three governments, the United Kingdom, Australia and New Zealand as the British Phosphate Commissioners to «make provision for mining of the phosphate deposits on the said Island»(Preamble), "under the direction, management and control of the Commissioners" (Article 8). The most contentious point was stated in Article 6:

«The title to the phosphate deposits on the Island of Nauru and to all land, buildings, plant and equipment on the island used in connexion with the working of the deposits shall be vested in the Commissioners.» (Article 6)

Nauruan rights to their island were totally set aside.

The Nauru Island Agreement pre-empted the terms by which the island was to be administered under the newly created 1920 League of Nations Mandate following the end of World War I. Under Article 22 of that Mandate proper discharge of mandate responsibilities required:

«there should be applied the principle that the wellbeing and development of such peoples [to which the Mandate applied] form a sacred trust of civilisation.»

The uK Commissioner reminded the other Commissioners from time to time that they had a development commitment, but this was set aside by confusion of the roles of administration of island affairs and the role of mining administration, both under the aegis of Australia's Canberra government. The demands of development of mining outweighed the demands of island development. Mining greed pre-empted social developments.

Throughout three quarters of the $\mathrm{xx}^{\text {th }}$ century, Nauruans lostautonomy over their peopleand their land firstly when the Pacific Phosphate Company established the phosphate mine on Nauru, and latterly when BPC took over responsibilities for mining and administration. Nauru had been annexed by Germany in 1888 at the request of the head chief of Nauru in order to end the civil war that was raging throughout the 1880s. Establishment of peace was achieved by German authorities working through the tribal chiefs. Nauruans still maintained their social controls, well documented in the detailed ethnographic accounts of the time (e.g. Hambruch, 1914; Kayser, 1935; Kretzschmar, 1913; Wedgwood, 1935) until their rights were abrogated by the Nauru Island Agreement (1919) that established the British Phosphate Commissioners in charge, with Australia as chief administrator of the island affairs, and of the mine.

Nauruans' pressure on Administrators from 1921 onward up to independence in 1968 expressed their views on how their rights were being set aside by BPC interests in profits from mining. A series of leaders emerged to maintain the pressure, despite the Administrator's attempts to brush them aside. In 1927 the Administrators established a Council of Chiefs, consisting of twelve selected leaders, one for each district. This violated the Nauruan tribal structure, chiefly hierarchy, and district administration, but under the leadership of Timothy Detudamo Nauruans gave lip service to administrative proposals, while maintaining their own political and class structure.

In 1952, after the disastrous reduction of their population during World War II, Nauruans established the Nauru Local Government Council in order to try to regain some control over their own affairs and their lives, and establish new less hierarchical leadership channels. Leaders emerged in the process of presenting their case for their rights to the Australian administrators, and to UN Trusteeship Visiting Missions. Several men such as Timothy Detudamo who bridged both traditional and modern state of affairs, and Pastor Jacob Aroi took on the task of confronting the administration continuously with various

2. The Commission of Enquiry into Worked out Mines was set up by President Hammer de Roburt, in conjunction with AusAid, Canberra, in 1983. The team of 17 consisted of 15 Australian experts, Lagi Harris representing the Nauru Government and myself, anthropologist, a New Zealand/British female. My role was to liaise with Lagi Harris to seek out the wishes of the Nauru people. He and I conducted consultative meetings in the twelve districts, and Lagi was formulating a video to explain the options for rehabilitation, but unfortunately he died before it was completed. 
aspects of their case both for greater financial returns and for more social improvements.

Led by a number of able educated Nauruans, who were learning more about their rights under the development criteria of the League of Nations, then the United Nations, the NLGC collated their case to a series of UN Visiting Missions in 1950s and 1960s. They voiced their strong desire for assistance with clarification of the financial affairs of the administration and the mine, and to reject Australia's attempts to move them off their island in 1960s. These concerns paved the way for the concerted claim for "damages under international trusteeship" against the British Phosphate Commissioners and Australia in particular, as discussed below.

After independence under Hammer de Roburt's leadership, Nauruans formulated their plans to obtain redress for past injustices by the BPC; that was the key issue at the centre of the Report of the Commission of Enquiry on the Rehabilitation of Worked out Phosphate lands on Nauru, 1988. Nauruans had long been concerned that their land was being taken without their agreement, and the many injustices they had endured. But they had lacked support for case until members of the visiting missions of the un Trusteeship Council assisted their case. Nauruans struggle earned them their independence in 1968.

Nauruans were outnumbered on their island by imported labour for the first half of the $\mathrm{xx}^{\text {th }}$ century. Of the 1,000 Nauruans living on their island when mining began in 1906, the men chose not to work in the mines, because they did not have the skills, nor the desire for that "work". The Pacific Phosphate Company began importing labour from China and various parts of the Pacific, particularly Gilbert Islands (now Kiribati) as the main manpower that became essential to keep the mine operating (Ellis, 1935). Contract worker numbers exceeded the total number of Nauruans through to the 1950s. Nauruan population growth suffered major setbacks during World War II when 1,200, i.e. two thirds of the Nauruan population, was exiled to Truk/Chuuk by the occupying Japanese force, resulting in many deaths; only 487 Nauruans returned home in 1946 to join those left on Nauru to work for the Japanese. They faced a major rebuilding exercise. Destruction of the island had been further exacerbated by American bombing of Japanese military installations across the island (Pollock, 1998). After the War the British Phosphate Commissioners' eagerness to restart mining operations placed strong emphasis on rebuilding their labour force, and humanitarian support for them. Housing became a contentious issue as the BPC administration built new housing for the new contract labour force, while Nauruans' own housing needs were overlooked. This dispute led to racial flare ups, and the whole affair was brought to the attention of the first United Nations Trusteeship Visiting Mission in 1952. The outside world gradually became aware of some of the non-development that Nauruans had been experiencing.

The Nauruan population has grown to over 9,000 at the start of the $\mathrm{xxI}^{\text {st }}$ century (2002 census). Until 2006 mining had continued to draw on contract workers who resided on the island during the terms of their contract. 4,000 mainly iKiribati (Gilbertese) were sent home in 2006 as mining diminished. But in 2008, and again in 2012, Australia made arrangements for their unwanted «boat people» from various parts of Asia to be established in a refugee camp on Nauru, until Australia sorted out their futures. These 4,000 outsiders have placed a heavy drain on Nauru's local resources (Pollock, 1998). Nauruans have ceded some autonomy in return for much needed government assistance from Australia.

\section{Welfare Issues}

In 1920 responsibility for Nauruan welfare was mandated to BPC in general, and Australia in particular, to be superseded later by the United Nations Trusteeship arrangements. Developments that should assist Nauru to improve their well-being were a major entailment for the three nations' commissioners. But these were largely sublimated by Australian focus on mining profits. Any developments, such as health care, education, political and administrative skills, and housing were introduced for all residents of the island. Nauruans failed to receive any specific benefits. Yet the bills for ever rising costs of Administration were paid for out of Nauruan phosphate money.

The Australian administration established a hospital for Nauruans, together with a separate hospital for non-Nauruans. Primary schools were established around the island to educate both Nauruans and the children of the contract labour force, mainly Gilbertese children. A long apartment building known as the Gilbertese settlement was erected on the south west shoreline, to house Gilbertese families, and some Ellice island workers. Later residences for Filipino and other contract staff were all paid for out of the Administration fund. Administrative staff were housed in more modern buildings, set above the shore-line.

Roads, and other amenities, as well as a police force, a gaol, and other "developments» were all paid for out of the Nauruan Administrative fund. Bpc bore the costs of the new technology, including a rail system, a storage system for processed super phosphate, and the cantilever and mooring systems that enabled ships to load ships direct from shore into ships' holds. 
By 1966, when Nauruans were strongly pushing for independence, Administration costs had risen to almost 100,000 Australian pounds; that represented $20 \%$ of the value of phosphate exports at that time (Viviani, 1970: Table 11, 190-191). Nauruans shares in «developments" with all other temporary residents on the island brought few advantages of modernisation. They had no say in how money was allocated, but became reliant on a consumer economy.

The health of Nauruans was reported annually, including those with leprosy, and other infectious diseases. By 1980 the numbers of Nauruans with high rates of Body Mass Index (вмI) led an epidemiologist team to declare an «obesity epidemic» which drew much media attention (e.g. Zimmet et al., 1977). The medical team attributed the obesity to consumption of large amounts of junk food as a result of the so-called «wealth» from phosphate mining (Zimmet et al., 1977). The Obesity label has persisted; World Health Organization placed Nauru at the top of their 2002 ranking of 170 nations worldwide according to their rates of BMI. The direct links drawn between increased wealth, poor food choices and obesity do not consider pre-cursive events. The need to preplace pandanus, coconuts and fish with store bought foods, but limited cash, was a necessary consequence of mining; choices of foods were limited. Nauruan cultural fattening of young women pre-mining may have lingering genetic implications. Obesity and high rates of BMIs provide a further example of the long-term negative impact of mining exploitation on creating a state of dependency. It is a direct outcome of the long term negative impact of mining (Pollock, 1995, 2012).

Nauruans responded strongly to Australian manoeuvrings in the early 1960 s to take them off their island and relocate them to share Curtis Island off the north east Australian Coast with another population. Australia could then mine the rest of the phosphate with contract labour for their own profits, without any «development» concerns for Nauruans. The Nauru Local Government Council expressed their very strong opposition to this move to Visiting Missions from the un Trusteeship Council, winning the backing of members of those Missions. Nauruans were concerned to hold on to their island at all costs. Such suggestions only hardened their resolve to gain independence, and as soon as possible.

\section{Rehabilitation of the Island Environment}

Nauruans' concerns for the future of their island that began in the 1920s and 1930s, was expressed in poetry, as well as in representations to successive administrators. Establishment of a Rehabilitation Trust Fund, into which a small proportion of Nauruans' funds was allocated only partially alleviated those concerns. After independence in 1970, and Nauruan purchase of mining assets for $\$ 21$ million, Hammer de Roburt and government officials began concerted efforts to address their right to compensation for loss of income from phosphate sales, and to rectify the destruction of Top Side. Upon completion of that purchase, as Weeramantry argued the Nauruan case:

«the Commissioners had a clear obligation under international law to give back to the Nauruans capital assets bought with phosphate moneys. Instead they sold the assets on the ground to the Nauruans [...] ignored the benefits they had collected in the form of capital assets overseas, and finally when the office of the British Phosphate Commissioners ceased to exist [in 1987] appropriated those assets into the treasuries of the partner governments, to be distributed from that source as largesse to other countries with no reference whatever to the Nauruans.» (Weeramantry, 192: 272)

Furthermore the Commissioners ignored Nauruans' requests to desist from distributing those assets until the situation was clarified by the work of the Commission of Enquiry.

The Commission of Enquiry into the Worked out Mines on Nauru, as proposed by the Nauru government in 1984, established a platform for their formal complaint. Since independence, Hammer de Roburt and other Nauruan leaders realised much information was missing, including all statements of financial transactions since 1921, but vital if they were to formulate a strong case for restitution of their rights. The Commission of Enquiry produced a series of recommendations from various outside experts for the future of the island (Commission for Rehabilitation of Worked Out Mines on Nauru, 1996). Funded jointly by Australian Aid and the Nauru government the Commission's work and final report has been maintained under strict control by the Nauru government.

That Commission of Enquiry drew on advice from 17 experts including a geologist, an engineer, a calcite expert, a housing advisor, botanists and post-mining assessors and a social anthropologist to liaise with a senior Nauru government representative. Recommendations included assessment of the feasibility of cutting down the pinnacles to re-construct a flat surface on Top Side, relocation of the airport and other amenities to that newly flattened area, thereby releasing considerable acreage on the flat southeast coastline for future residential developments. Women wanted new housing "Toorak style» provided along the edge of Top Side, while a class of one Primary School overwhelmingly favoured a "park» amongst trees on Top Side with trees, play equipment and 
barbeque areas. Relocation of the airport, and the secondary school were strongly supported suggestions.

As a result of the hearing of Nauru's case by the International Court of Justice in The Hague, the Nauruan people were awarded compensation money amounting to $\$$ A210 millions under the Nauru/Australia Compact of Settlement Treaty (Reyes, 1996). A further \$A12 millions each from the United Kingdom and New Zealand was to be paid to Nauru by these lesser partners in the mining gains. The Australian payment was to be spread over 5 years, with rehabilitation activated by the Nauru Rehabilitation Corporation. The question of the «extinguished» Trust Funds was left for the Nauru government to pursue.

Nauruans' dreams for their future have been formulated in terms of a "return to the Garden of Eden" as President Dowiyogo expressed their future to a Sustainability Development conference in the Bahamas in 2001. They want Top Side to be a green and usable area. Their considerable concerns about how their island is likely to be affected by sea level rise of the Pacific Ocean, particularly on their fresh water supply, and acidification of the ocean around Nauru that is affecting fishing were voiced at the Majuro Agreement arising from the August 2013 Pacific Forum meeting on Climate Change in the Pacific (see Pollock, 2014, for details).

Nauru's future without phosphate and no viable means of support, other than aid money, provides a new dimension to considerations for their future. The natural resource curse that is mining has long term implications both for the economic and humanitarian wellbeing of the Nauru people.

\section{Conclusions}

The Nauru case of the impact of phosphate mining on the lives of a small island people in mid Pacific presents a striking example of the natural resource curse thesis. It underlines how mining for phosphate has minimized Nauruan rights and brought few development advantages. Nauruan autonomy was overridden by external commercial exploitation. The economics of extracting phosphate dominated while humanitarian issues arising from imposed commercial activity were sublimated. Responsibilities for "developments» called for in the League of Nations Class C MandHughesate, succeeded by the United Nations Trusteeship, were only peripherally activated.

Nauruans only answer to loss of autonomy and thus control over their own lives was to coordinate their claims for independence, and then seek reparations from the British Phosphate
Commissioners. Trust in outside management/ administration had been thoroughly undermined as they began to discover, post-independence, just how actively the "curse» of phosphate had diminished their chances for a future after mining. Degradation of their island environment resulted in a major loss that is proving very costly and difficult to rectify 50 years later. The Commission of Enquiry into Worked Out Mining areas provided some pointers, but all have proved very costly and impractical according to Nauruan values. Successive governments have yet to find a solution. Political instability tied to a murky financial stability is the legacy (Stiglitz, 2006: 136).

Nauru's litany of woes attributed to the natural resource curse extend beyond the early mis-representations of Nauruans as "wealthy" in financial terms to the failure of phosphate mining to advance their welfare and well-being, and a new label as a «failed state». Those woes continue to exist as successive governments are charged with finding a solution. Nauruans cling to their island as their homeland, while seeking advice that is acceptable to their own values.

\section{BIBLIOGRAPHY}

Auty Richard, 1993. Sustaining Development in Mineral Economies: The Resource Curse Thesis, London, Routledge.

Brown Anne M. (ed.), 2007. Security and Development in the Pacific Islands, London, Lynne Rienner publishers.

Clark Dymphna and Stewart Firth, 1992. Nauru 1888-1900, An Account in German and English of official records collected by Wilhelm Fabricius - records of the Colonial Section of the German administration, Canberra, Australian National University, Division of Pacific and Asian History, RSPACS.

Commission for Rehabilitation of Worked Out Mines on Nauru, 1996. Report in 6 volumes, Nauru Government.

Dowiyogo Bernard President, 2001. Can we recreate the Garden of Eden that once was Nauru, Bermuda, Proceedings of Global Conference on Sustainable Development of Small Island developing States.

ELLIS Arthur F., 1935. Ocean Island and Nauru, Sydney, Angus and Robertson.

Hambruch Paul, 1914. Nauru, in G. Thilenius (ed.), Ergebnisse der Südsee-Expedition 19081910, II: Ethnographie, B. Mikronesien, vol. 1, part 1, Hamburg, L. Friedricksen. 
KaYser Alois, 1935 (2005 translation). Nauru One Hundred Years Ago, Suva, Institute of Pacific Studies, University of the South Pacific Centre on Nauru.

Kretzschmar K.E., 1913. Nauru, Nauru, Mission Press.

Nauru Island Agreement, 1919. Reprinted in C. Weeramantry, 1992. Nauru: Environmental Damage under International Trusteeship, Melbourne, Oxford University Press, appendix I, pp. 375-378.

Pollock Nancy J., 1986. Land Report to Nauru Commission of Enquiry, Commission records MD7.

-, 1995. Social Fattening Patterns in the Pacific, in I. De Garine and N. J. Pollock (eds), Social Aspects of Obesity, Amsterdam, Gordon and Breach.

—, 1998. Decolonising, Recolonising - but never a colony, in Emerging from Empire? Decolonisation in the Pacific, Canberra, ANU Press, pp. 102-106.

-, 2009. The Frigate Bird Cult in Eastern Micronesia, People and Culture in Oceania 25, pp. 97-100.

—, 2012. Obesity on Nauru, paper for ASAO session on Obesity, Manuscript.

—, 2014. Social Impact of Mining over the $\mathrm{xx}^{\text {th }}$ century on Nauru, Manuscript.

Quanchi Max 2007. Troubled Times: Development and Economic Crisis in Nauru, in A. Brown (ed.), Security and Development in the Pacific Islands, New-York, Lynn Rienner, pp. 249-264.
ReYes Raymon E. Jr., 1996. Nauru v Australia. The International Fiduciary Duty in the settlement of Nauru's claims for Rehabilitation of its Phosphate lands, New York Law School Journal of International and Comparative Law, special edition 16 (1 \& 2), pp. 1-54.

Rosser Andrew, 2006. The Political Economy of the Resource Curse. A literature survey, Brighton, Institute of Development Studies, IDS Working Paper 268.

SACHS Jeffrey and Andrew Warner, 2001. The Curse of Natural Resources, European Economic Review 45, 4-6, pp. 827-838.

Sen Amartya, 2001. Development and Freedom, New-York, Oxford University Press.

Stiglitz Joseph, 2006. Making Globalization Work, New York, WW Norton \& Co.

Viviani Nancy, 1970. Nauru: Phosphate and Political Progress, Honolulu, University of Hawaii Press.

Weeramantry Christopher, 1992. Nauru: Environmental Damage under International Trusteeship, Melbourne, Oxford University Press.

Wedgwood Camilla, 1935-1936. Report on research work in Nauru, Central Pacific, Oceania 6, p. 7.

Zimmet P., P. Taft, A. Guinea, W. Guthrie and K. Thoma, 1977. The High Prevalence of Diabetes Mellitus on a Central Pacific Island, Diabetologia 13, pp. 111-115. 


\section{Vient de paraître}

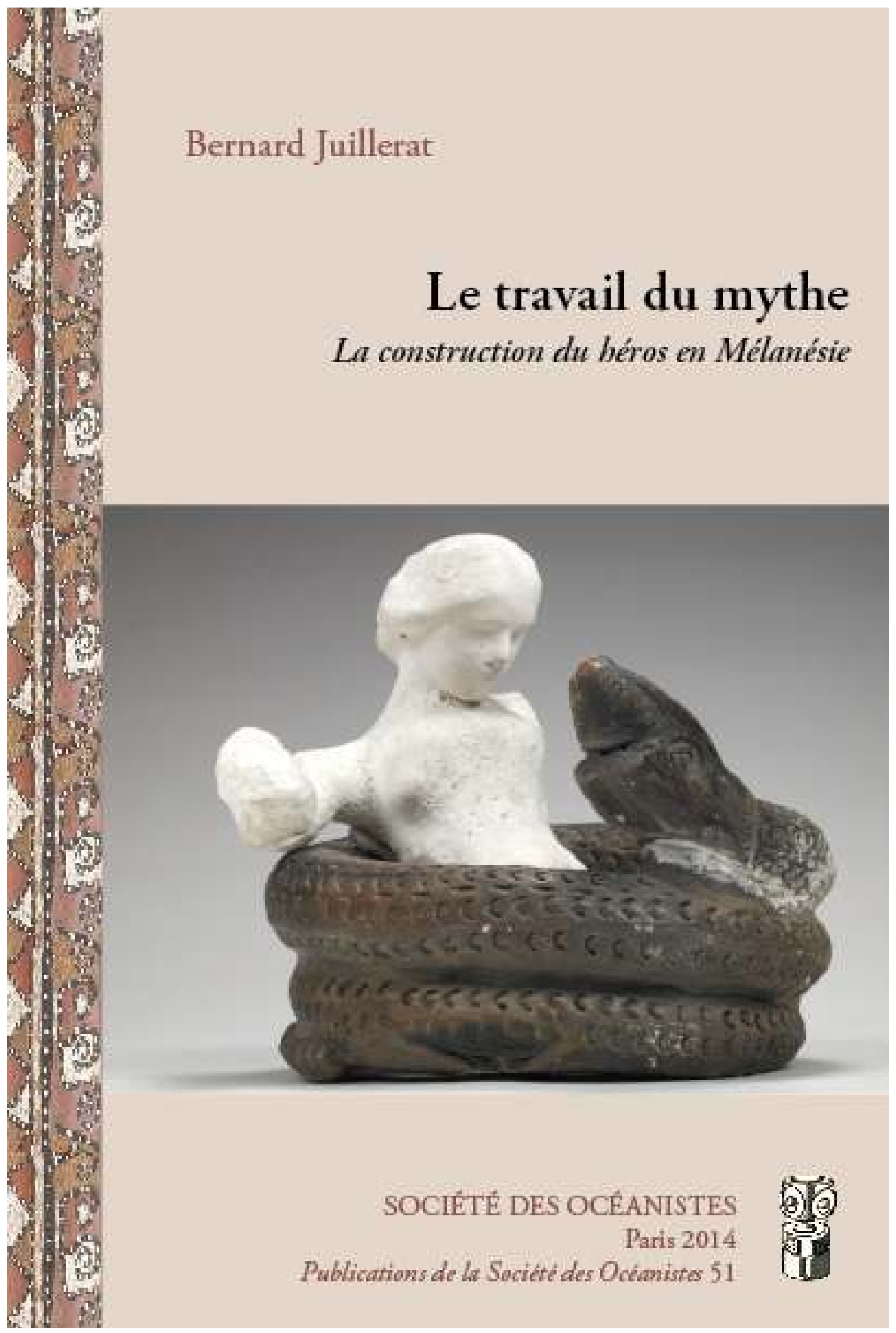

Disponible sur le site internet de la Société des Océanistes (http://www.oceanistes.org/oceanie/ spip.php?article3891) et à la librairie du musée du quai Branly au prix de $19 €$.

Version pdf disponible sur http://books.openedition.org/sdo/1213 au prix de 14,99€. 